\title{
Urban flash flood in Gdańsk - 2001. Case study
}

\author{
Wojciech Majewski \\ Institute of Meteorology and Water Management - National Research Institute, Podleśna 61, 01-673 Warsaw, Poland, \\ e-mail:wmaj@ibwpan.gda.pl
}

\begin{abstract}
Gdańsk is an important Polish city and harbour situated on the southern coast of the Baltic Sea in the Gulf of Gdańsk, in the lowland delta at the mouth of the Vistula River. At present Gdańsk has 460 thousand inhabitants and covers an area of $262 \mathrm{~km}^{2}$. The population and the area of the city have not changed over recent decades. In previous centuries the city was affected by severe floods, which caused considerable economic damage and the death of inhabitants. Most of these floods were caused by ice jams. The complicated system of rivers and channels within the city and in its close surroundings is called the Gdańsk Water Node (GWN). The possible directions of flood hazard are: from the sea (Martwa Vistula), and from the main Vistula channel in the case of a breached left embankment. Flood hazard from the catchment of the RCh was not considered by city authorities.

In July 2001, a devastating flash flood unexpectedly hit the city of Gdańsk. The paper presents this flood as a case study, without reference to other floods of similar character. It describes the city of Gdańsk, which is an important economic, cultural, scientific, political and industrial center, the system of rivers and channels within Gdańsk which form Gdańsk Water Node (GWN), the precipitation regime, the course of the flood, and its effects. A special project was formulated after the flood with the aim of developing the proposal of new hydraulic engineering solutions in the GWN and in the catchment of Radunia Channel to prevent similar floods in the city in cases of rainfall similar to that of 2001. The paper also presents the implementation of the proposed engineering solutions.
\end{abstract}

Keywords: Gdańsk, urban flash flood, Radunia Channel, Gdańsk Water Node, engineering proposals

Submitted 28 October 2015, revised 29 March 2016, accepted 11 August 2016

\section{Introduction}

Many cities are situated along rivers or in coastal areas: this gives them a significant advantage in the form of cheap water transport, hydropower, water supply, fisheries and recreation. However, rivers cause floods and in coastal areas inundation may result from storm surges. Floods in urban areas are very dangerous as they usually cause considerable economic and social losses. The situation in respect of floods is deteriorating due to the increasing number of people living in cities, in river valleys and in coastal zones. Moreover, floods, especially in Europe, are appearing more frequently than previously and cities are more vulnerable to inundation (Majewski 2003a).

At present, the increased vulnerability of cities to floods needs to be considered as city infrastructure develops rapidly and becomes more valuable. This infrastructure is prone to flooding, and its protection against inundation is difficult and expensive. By means of engineering solutions we can manage flood protection, though only up to a certain water level or discharge. It is not possible, however, to either afford or achieve full protection, as higher discharges than the design discharge, or higher water levels, can appear. A very popular approach so far has been flood protection, designed for floods of a specific probability though not considering those of lower probability. Flood management, however, takes into account the whole range of potential floods using technical and non-technical solutions. It considers the reduction of all flood losses and the minimisation of the loss of life. In 2007, a new EU Flood Directive was introduced which changes the approach to flood management. It considers flood risk management, which is the product of flood probability and the vulnerability of a given area to inundation.

Flash floods, which appear in cities, are caused by very intensive precipitation with the resulting amount of water becoming too much for the discharge capacity of rivers, streams, channels or storm drainage systems. Good meteorological forecasts are very important in order to prepare people for such events.

In cities, storm drainage systems that were designed in the past are not currently sufficient for very high rainfall; this results in the flooding of streets and underground facilities. Another disadvantage in cities is a fast runoff caused by large areas of impermeable surfaces (roofs, streets, car parks etc.). It must also be emphasised that each city has its specific character, determined by its spatial layout, relief and hydro-meteorological conditions. It is therefore 
difficult to apply a flood experience from one city directly to another. The development of a city should take into account the increase of possible flood risk in new districts, as well as within the city as a whole. Cities should also be equipped with efficient hydro-meteorological measuring systems, which can be used as decision support systems.

In July 2001, a devastating flash flood unexpectedly hit the city of Gdańsk (Majewski 2002). The paper presents this flood as a case study, without reference to other floods of a similar character. It describes the city of Gdańsk, which is an important economic, cultural, scientific, political and industrial center, the system of rivers and channels within Gdańsk which form the Gdańsk Water Node (GWN), the precipitation regime, the course of the flood, and its effects. A special project was formulated after the flood with the aim of developing the proposal of new hydraulic engineering solutions in GWN and in the catchment of Radunia Channel ( $\mathrm{RCh}$ ) to prevent similar floods in the city in cases of rainfall like that of 2001. The paper also presents the implementation of the proposed engineering solutions.

\section{The city of Gdańsk}

Gdańsk is an important Polish city and harbour situated on the southern coast of the Baltic Sea in the Gulf of Gdańsk, in the lowland delta at the mouth of the Vistula River. At present Gdańsk has 460 thousand inhabitants and covers an area of $262 \mathrm{~km}^{2}$. The population and the area of the city have not changed over recent decades (Szermer 1971). In previous centuries the city was affected by severe floods, which caused considerable economic damage and the death of inhabitants. Most of these floods were caused by ice jams, which formed on the delta branches of the Vistula as a result of their complicated layout. To prevent these ice jams, the layout of the final section of the Vistula was radically changed at the end of the $19^{\text {th }}$ century with the formation of a direct channel to the sea; this is known as the Vistula Przekop (VP). The old branches of the Vistula were separated from the main channel by navigation locks and storm barriers. Since that time there has been no ice jam flood over the Vistula delta, although during very cold winters the final section of the Vistula is covered with thick ice cover and the assistance of icebreakers is indispensable for preventing ice jams (Majewski 2010).

Possible flood hazards in the area of Gdańsk are expected from the main Vistula channel in the case of a very high discharge or ice jams, and from the direction of the sea in the case of a high water level in the Bay of Gdańsk being accompanied by a severe storm surge. The probability of a flood caused by intensive precipitation is rather low and was not seriously considered, although the engineering community has warned city authorities about the possibility of such a flood. In July 2001 Gdańsk was hit by a severe flash flood, which came for the first time from the moraine hills.

\section{Gdańsk Water Node}

The complicated system of rivers and channels within the city and in its close surroundings is called the Gdańsk Water Node (GWN) (Fig. 1). The north-west part of the city of Gdańsk is not shown in Fig. 1. Approximate city boundaries are indicated by a dashed line. Arrows show the possible directions of sources of flood hazards. These are: from the sea (Martwa Vistula) and from the main Vistula channel in the case of a breached left embankment. Flood hazard from the catchment of RCh was not considered by city authorities.

Several small rivers drain into the Martwa Vistula, which has a direct connection with the Gulf of Gdańsk, where water levels change due to winds and differences in pressure. Its maximum range (min. - max.) can reach $1.50 \mathrm{~m}$. To prevent the inflow of saline waters from the sea into rivers, channels and streams discharging into the Martwa Vistula, special storm gates were installed; these close automatically when the water level in the Martwa Vistula is higher than in the land tributaries. There are two main storm gates on the Motlawa Moat (Opływ Motławy). They are indicated by numbers 1 and 2 in Fig. 1. These storm gates were installed at the end of the $20^{\text {th }}$ century. Mottawa Moat now plays the role of a small retention reservoir. In the past this water body formed a defensive moat for the city of Gdańsk (Jasińska 2002).

In the GWN there are two small but important rivers: the Motława and the Radunia. The Motława River discharges into the Martwa Vistula through several branches within the city of Gdańsk. The Radunia River flows towards Gdańsk from the moraine hills and discharges into the Motława River (Fig. 1). The Radunia River, due to high slopes, has the character of a mountain river. Another tributary of the Motlawa is the Kłodawa River. Its right-hand embankment was breached during the flood (Fig. 1). Kłodawa River is outside the boundaries of the city of Gdańsk.

In the $14^{\text {th }}$ century an artificial channel, called the Radunia Channel (RCh), was constructed. It branches from the Radunia River near Pruszcz Gdański. The right-hand embankment of the channel was formed of sheet piling and local soil. The aim of this channel, which runs at the foot of the moraine hills, was to supply good quality water to the city of Gdańsk. The initial section of the RCh runs 


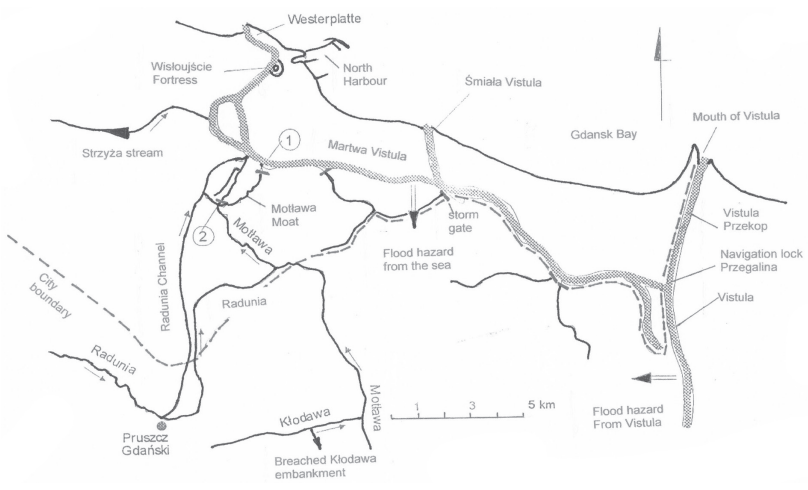

Fig. 1. Gdańsk Water Node

parallel to the Radunia River. The total length of the channel is $13.5 \mathrm{~km}$; its catchment is on the moraine hills, totally on the left side, and amounts to $55 \mathrm{~km}^{2}$. There are several small natural streams and outlets from city storm drainage networks on the catchment of the RCh, and which discharge into it. Their discharge in normal conditions does not exceed $1 \mathrm{~m}^{3} / \mathrm{s}$. The RCh also plays the role of an artificial storage reservoir. The total water volume of the channel is estimated at about $300000 \mathrm{~m}^{3}$. The average slope of the channel is $0.5 \%$, and its discharge at maximum depth of $3.0 \mathrm{~m}$ is estimated at about $20 \mathrm{~m}^{3} / \mathrm{s}$. The RCh is a righthand tributary of the Motława River within the city and has one artificial right-hand outlet to the Motława Moat. The right side embankment of the RCh runs parallel to the main road leading to Gdańsk from the south. The area along the right bank of the $\mathrm{RCh}$ is occupied by the old part of the city, which is situated in a depression.

In recent years the city has expanded towards the moraine hills which form the catchment of the channel; this has increased the runoff from this area considerably. Intensive precipitation over this area always results in intensive runoff and in 2001 it was the main reason for the flood, as the RCh could not accommodate and discharge downstream flood water which had discharged into it from the catchment.

The Strzyża Stream is within the city of Gdańsk; however, it is outside the catchment of the RCh (Fig. 1). It discharges into the Martwa Vistula. The Strzyża Stream flows through the city and has several small reservoirs. It flows partly as an open channel, but also as an underground conduit. The dam of the reservoir shown in Fig. 1. was breached during the 2001 flood.

\section{Precipitation regime}

Precipitation in Gdańsk is highly non-uniform in both space and time. There have been frequent very intensive rainstorms within the city which only covered, however, small areas. The precipitation regime is determined on the basis of existing measurement data.

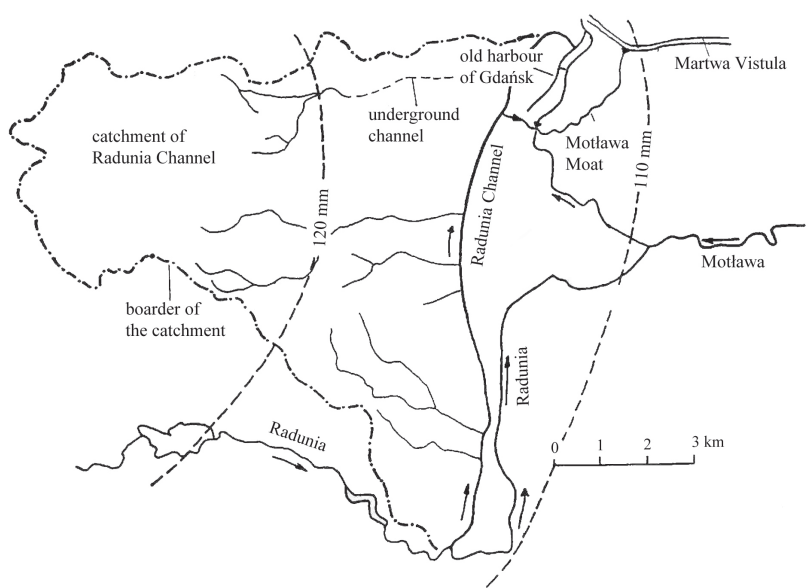

Fig. 2. Amount of precipitation over the RCh catchment on 9th July 2001

The average yearly precipitation in Gdańsk is about $600 \mathrm{~mm}$, the July average being $68 \mathrm{~mm}$. Before 2001, the maximum daily precipitation recorded, in July 1980 , amounted to $80 \mathrm{~mm}$. In recent years it was observed that the maximum daily precipitation in the Gdańsk area shifted from spring months to July (Majewski 2002).

On the $9^{\text {th }}$ of July 2001 practically the whole catchment area of the RCh received $80 \mathrm{~mm}$ of precipitation within only 4 hours. The daily amount of precipitation in Gdańsk on $9^{\text {th }}$ July 2001 was estimated to be between 110 and $120 \mathrm{~mm}$ (Fig. 2). The upper part of the catchment received $120 \mathrm{~mm}$ and the lower part, including the channel and its right-hand area, received $110 \mathrm{~mm}$. Precipitation distribution over the city of Gdańsk on the $9^{\text {th }}$ July 2001 indicates that the catchment of the channel was in the centre of maximum precipitation. This value was estimated to have a probability of 0.5 to $0.3 \%$ (once in $200-300$ years) (Majewski 2010).

The dramatic situation in the city was caused by the fact that flooding started within a very short time after the beginning of rainfall and the city infrastructure prevented the possibility of applying any technical protection measures.

\section{Course of the flood and its consequences}

Intensive precipitation resulted in the runoff being a kind of sheet flow over the whole channel catchment. The streams and subsurface storm drainage network were immediately full (Jasińska, Majewski 2004). This resulted in a very high inflow to the $\mathrm{RCh}$, which runs perpendicular to the main slopes. It was estimated that the inflow to the channel from its catchment exceeded $100 \mathrm{~m}^{3} / \mathrm{s}$ over 4 hours, while the RCh maximum discharge capacity was estimated at only $20 \mathrm{~m}^{3} / \mathrm{s}$. As a consequence of the very high inflow into the channel, the right side channel embankment 


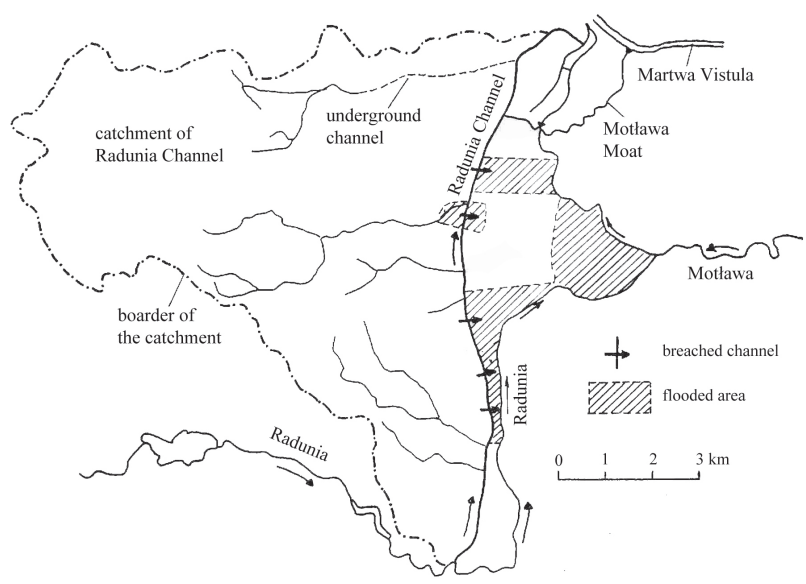

Fig. 3. Breached embankment of the RCh and flooded areas

overflowed, which resulted in its destruction, damage to city infrastructure and the inundation of large areas.

- The embankment of the RCh was breached in 5 places, which resulted in flooding of the part of the city situated on the right side of the channel and the main road (Fig. 3);

- Two main roads approaching Gdańsk from the west became torrential rivers. One of them is shown in Fig. 4;

- Gdańsk main railway station was flooded, which caused one week's stoppage in rail traffic (Fig. 5);

- The head dam of the reservoir on the Strzyża Stream in Gdańsk was breached, which resulted in a severe flood along the main street and flooding of the crossing of the main road between Gdańsk and Gdynia;

- One day later $\left(10^{\text {th }}\right.$ July), the left side dyke of the Kłodawa River, situated about $10 \mathrm{~km}$ south of the $\mathrm{RCh}$, was breached, which resulted in the inundation of a large agricultural land (Fig. 6).

Destruction of the right side embankment of the RCh was the result of the overflowing water that the channel

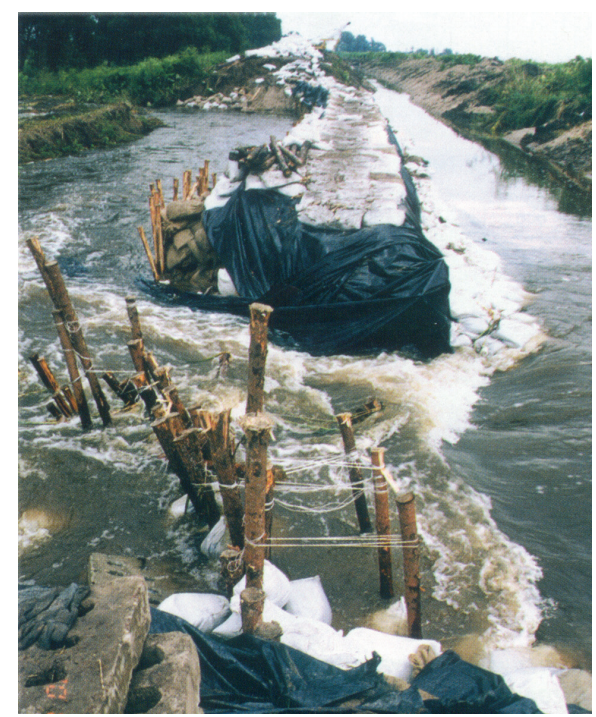

Fig. 6. Breached embankment of the Kłodawa River (Majewski 2010)

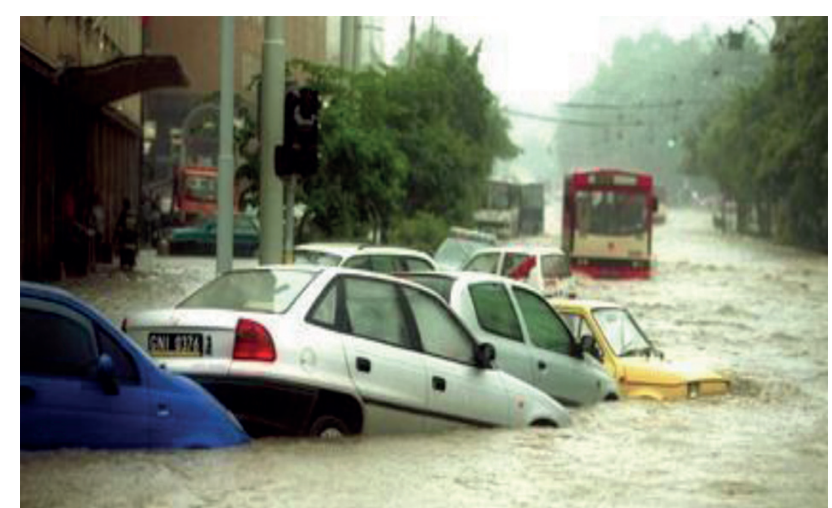

Fig. 4. Flooded main street in Gdańsk (Majewski 2010)

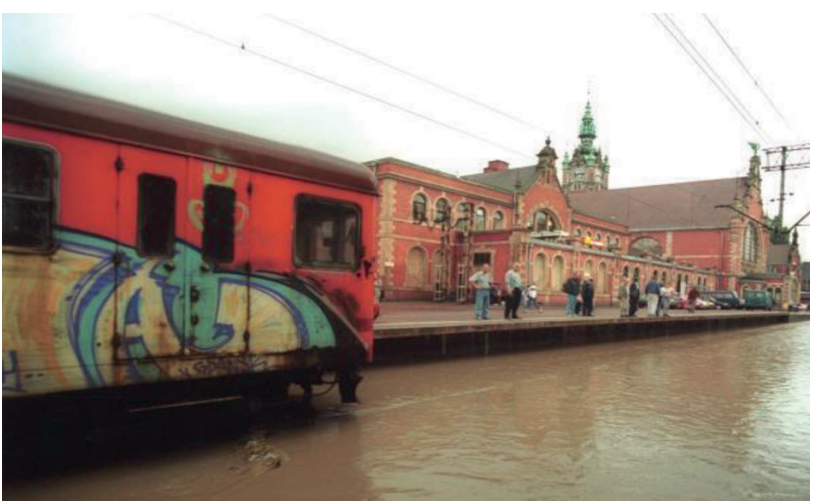

Fig. 5. Flooded Gdańsk railway station (Majewski 2010)

could not accommodate passing over its crest. The crest of the embankment was not protected against water overflow and the process of breaching proceeded very quickly as the main body of the embankment was constructed of soil. In some places destruction of the embankment was caused by a very strong river current discharging perpendicular to the channel. The destroyed embankment is shown in Fig. 7. In several places intensive water flow damaged the road that runs parallel to the channel (Fig. 8).

More than 300 families were affected by the flood (damaged houses, loss of property). It was necessary to rescue people and their property from complete loss and destruction. Basements of numerous houses were flooded and required draining and drying. About 5000 people received special calamity status, which results in social assistance. Total flood damage to the city infrastructure was estimated at about $€ 40$ million.

The embankment of the RCh was quickly provisionally repaired to prevent further flooding. Simultaneously, pumping was carried out to drain the flooded areas. The repairing of the streets and removal of sediment, which was carried by water and deposited on the main road, was a difficult and slow process (Fig. 9).

The breaching of the right-hand dike of the Kłodawa River caused a very dangerous situation, because the water level in the river was much higher than in the surrounding terrain. Therefore, the repair of the gap in the flood dyke 


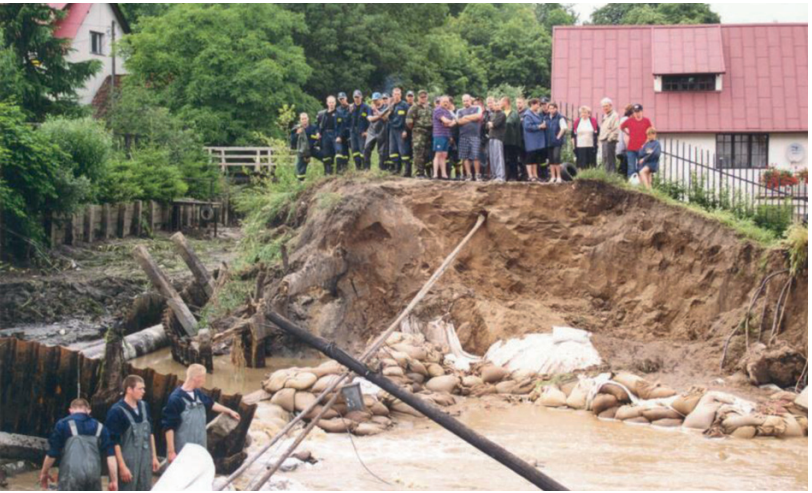

Fig. 7. Breached embankment of the RCh (Majewski 2010)

was urgent. Access to this place was unfortunately only over the narrow crest of the dyke. It took 2 days to complete the task and a large volume of water discharged from the river and inundated agricultural terrain.

Another type of disaster occurred on the Strzyża Stream, which is outside of the catchment of the RCh. The artificial reservoir situated on this stream (within the city on one side of an important road) had outflow facilities which were not designed for water discharge with a large amount of debris - something that is usually the case during intensive runoff. In this situation, the outlet intake with trash racks was blocked by flowing debris and water flowed over the crest of the dam, thus eroding it and breaching. As a result, the whole volume of the reservoir was rapidly emptied, causing disaster along the main road and flooding for a long period the important crossing with the main road connecting Gdańsk and Gdynia. These events clearly show that the city was not prepared for such intensive precipitation.

\section{Flood protection project}

After the flood of 2001, the local authorities (the Regional Board of Water Management in Gdańsk) decided that it was necessary to undertake steps to improve flood protection in the Gdańsk area in future, especially in the region of the RCh (Majewski 2003b, 2004). The analysis of the existing spatial situation of the city indicates, how-

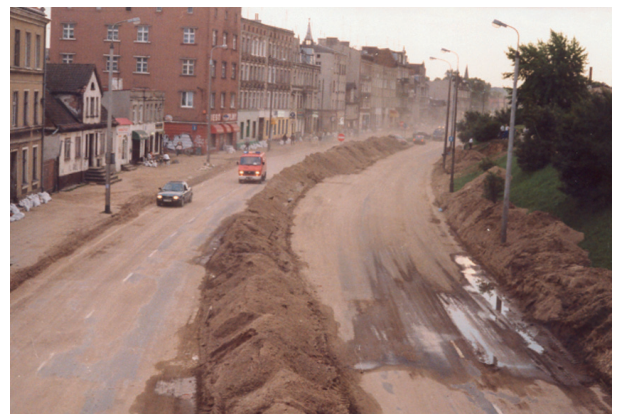

Fig. 9. Sand deposited on the main road after the flood (Majewski 2010)

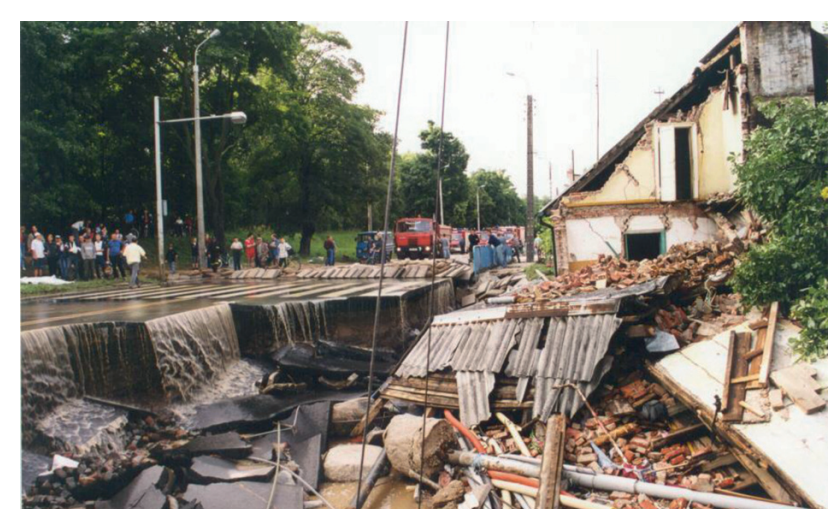

Fig. 8. Damaged main road entering Gdańsk (Majewski 2010)

ever, that the present infrastructure does not allow for any major change in the network of channels in the Gdańsk area. In order to solve this problem a special consortium was created. It consisted of four institutions, including research institutes, and design and consulting firms. The main tasks were defined as follows:

- measurements of all rivers and channels forming the Gdańsk Water Node (cross-sections and longitudinal profiles) to provide data for a mathematical hydraulic model;

- hydrological analysis of rivers and streams as well as water level changes in the sea (Gdańsk Bay);

- development of 1D unsteady flow model of the whole system of rivers and channels including all bridges and hydraulic structures;

- hydraulic calculations of various possible variants of flood protection;

- analysis of results and proposal of technical solutions.

Detailed information of all rivers, streams and channels was necessary for the formulation of the numerical model. It was decided that all existing cross-sections should be validated, as some of them were measured several years ago. More than 250 cross-sections of river channels were measured. In these cross-sections hydraulic structures, bridges and flood dykes were recorded. Current water levels were also measured. All the data were recorded in one unified geodetic system. Several data sets from previous measurements were compared and corrected. All these data formed the basis for the numerical model. Special attention was given to the height of dyke crests. It was found on numerous occasions that the local lowering of the dyke crest could have been the reason for its overtopping and subsequent breaching.

One of the main tasks of the project was the collection and analysis of hydrological data. These data concerned discharges and water levels in all rivers and streams of the GWN. It was also necessary to determine the probabilities of extreme discharges which could appear in the rivers Radunia and Motława. Simultaneously, changes in 
water levels over time in the Gulf of Gdańsk were also analyzed. The possible coincidence of high water levels in the Gulf of Gdańsk, and thus in the Martwa Vistula, together with high discharges in the rivers of the GWN were analyzed. These data were taken into account for subsequent hydraulic calculations. An important task was also the determination of the roughness coefficient of various river channels to include in the mathematical model. After detailed analysis of the streams in the GWN the value of the Manning roughness coefficient for hydraulic calculations was assumed as $n=0,030$.

The 1D unsteady flow model was developed on the basis of MIKE 11. The upstream boundary condition was the discharge in the Radunia and Motława Rivers. The downstream boundary condition was constituted by the water level in the Martwa Vistula. In the case of a rise in water level in the Gulf of Gdańsk, the storm gates close automatically and the downstream sections of the Motława and the Motława moat gradually fill with water.

A special part of the model was the RCh catchment. This was divided into sub-catchments of the streams and areas between them. Inflows to the Radunia Channel were determined by means of empirical formulas and the possibility of discharging this water volume downstream was calculated. In the majority of extreme situations it appeared that the discharge capability of the RCh was too small, and that controlled side outflows from the channel were necessary. All these situations were included in the model.

The main aim of the hydraulic calculations was the determination of flow conditions (water levels) during high discharges. Verification of the model was, however, possible for the section of Radunia and Motława Rivers only. Data for the verification included low discharges only, as water levels for high discharges were not available. This proved that the value of Manning roughness coefficient equal to $n=0.030$ gave good results.

\section{Results of calculations}

The first calculation concerned the determination of maximum discharge, which could be transferred through the system of rivers and channels without flooding the protected area. The second series of calculations was for the design discharge of $1 \%$ probability estimated from hydrological analysis. These calculations had to indicate in which places existing flood dykes were too low and needed to be raised. Calculations also indicated the need for increased retention in the catchment of the $\mathrm{RCh}$ in the form of small retention reservoirs, as well as additional outflows from the channel to the Motława and Radunia Rivers, as the discharge of the channel could not be increased beyond $20 \mathrm{~m}^{3} / \mathrm{s}$, because $\mathrm{RCh}$ is a historical construction and the proposed increases in discharge met protests from ecological organizations, which oppose substantial changes in the channel. A sample calculation of discharge in the Radunia River and water elevations along its $13 \mathrm{~km}$, run from the place where RCh branches (Pruszcz Gdański) to the place of discharge into the Motława River, are shown in Fig. 10. Hydraulic calculations also indicated that in some places only small changes in dyke height were necessary to increase the flow of flood waters.

On the basis of the hydraulic calculations and analysis of all the circumstances, it was decided that 18 small artificial storage reservoirs on all the streams discharging into the RCh should be constructed in order to decrease the inflow in cases of intensive precipitation. Their total volume was estimated at about $420 \times 10^{3} \mathrm{~m}^{3}$ and this is

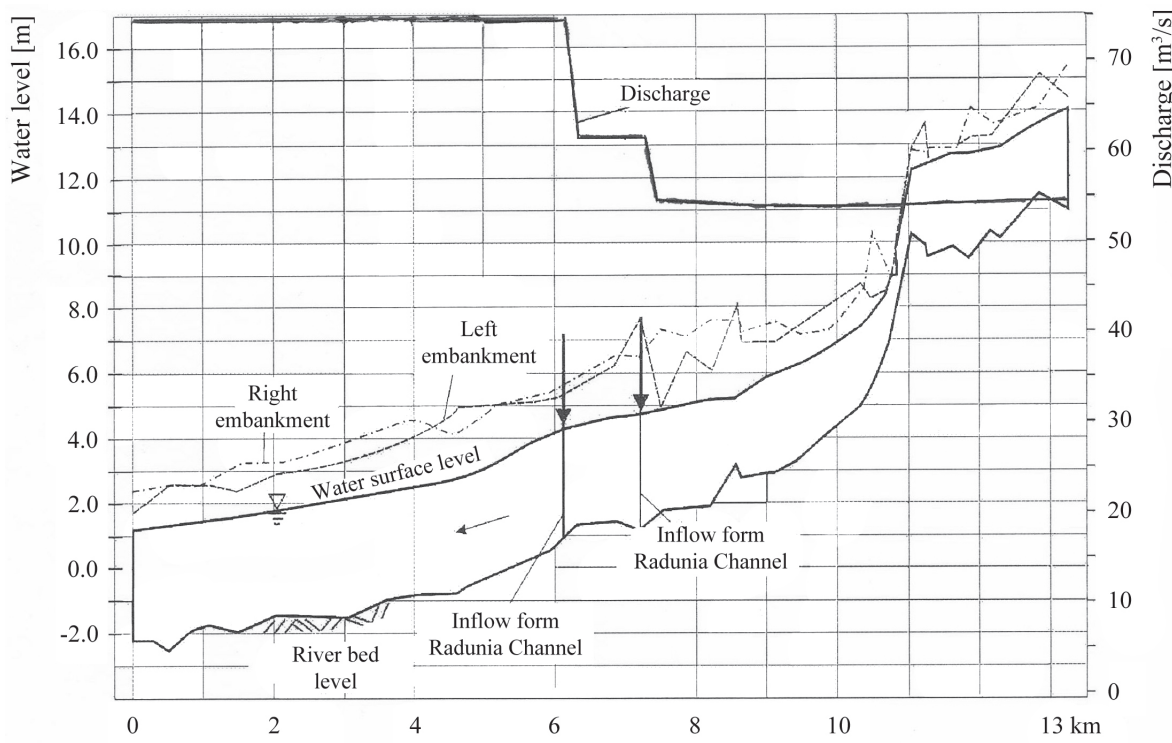

Fig. 10. Example of the results of calculations for the final section of the Radunia River 
not sufficient to accommodate all water from intensive rainfall. Therefore, it was also proposed that 4 control outflows from the RCh to the Radunia and Motława rivers be constructed to diminish the flow in the channel in cases of high precipitation. Two flood polders were also planned, which can be operated in cases of an extremely strong storm surge and simultaneous high water level in the Motława River, were also planned. The proposed solutions are shown in Fig. 11.

\section{Operation of storm gates}

Water inflow from the moraine hills to the Martwa Vistula cumulates in the River Motława, which, before flowing into Gdańsk, creates the reservoir in the form of the Motława Moat. Its surface area is about 20 ha, which affords the additional storage of about $200000 \mathrm{~m}^{3}$ of water. The Motława Moat is connected to the Martwa Vistula by means of two storm gates, which close automatically when the water level in the Martwa Vistula is higher than that on the landward side. There are six storm gates altogether (Fig. 1), however, the most important are the storm gates on the Motława Moat.

The Żuławska Storm Gate (No. 1 in Fig. 1) is at the end of Motława Moat and is directly connected with the Martwa Vistula. Kamienna Storm Gate (No. 2 in Fig. 1) is at the beginning of the Motława Moat and is connected to the Martwa Vistula through the section of the River Motława which flows through the city of Gdańsk. Four other storm gates, shown in Fig. 1, connect local channels only with the Martwa Vistula and are of minor importance.

The first discharge to the Motława Moat is in the form of a side outflow from the RCh. Its maximum capacity is $12 \mathrm{~m}^{3} / \mathrm{s}$. The next is the River Motława, which collects wa-

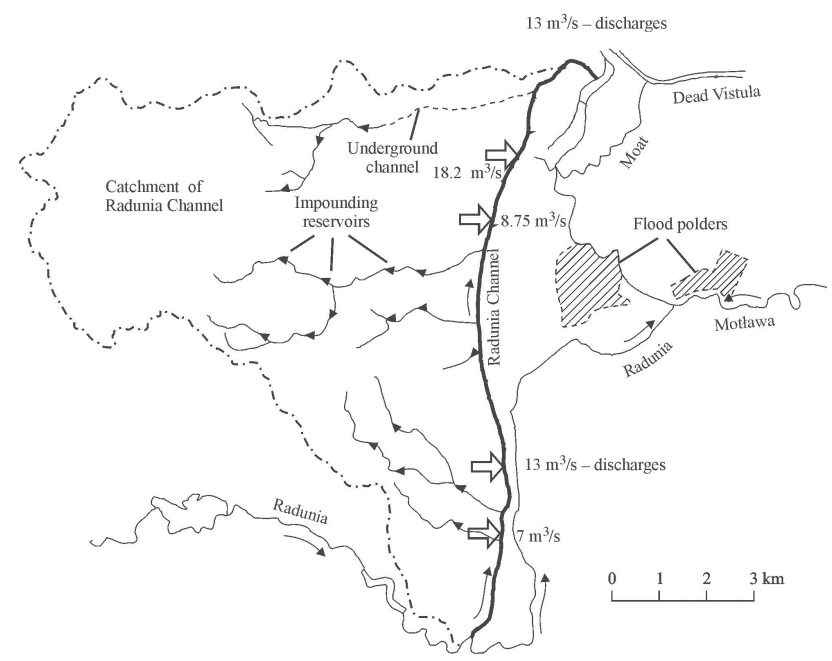

Fig. 11. Proposed retention reservoirs, additional outfalls from the $\mathrm{RCh}$ and flood polders ters from the River Radunia and other rivers. Maximum discharge of the River Motława at the inflow to Motława Moat is estimated at $90 \mathrm{~m}^{3} / \mathrm{s}$. This discharge changes with time. The hydrological analysis provides the discharges of all inflows according to the probability of their appearance.

There Martwa Vistula connects with the Gulf of Gdańsk in two places. One is through the main harbor channel near Westerplatte and the second is through the Śmiała Vistula (Fig. 1). It is assumed that changes in water level in the Martwa Vistula are the same as those recorded in the Gulf of Gdańsk. Hypothetical storm surges were assumed for various probabilities from $p=0.3 \%$ to $p=10 \%$. The average water level in the Martwa Vistula is about $0.40 \mathrm{~m}$ a.s.l. The maximum water level for a storm surge of probability $p=0.3 \%$ is $1.5 \mathrm{~m}$ a.s. 1 . and the time it takes to reach the maximum water level in the Martwa Vistula is about 16 hours. The maximum water level for a storm surge with probability $p=10 \%$ is $0.9 \mathrm{~m}$ a.s.1. The maximum permissible water level in the Motława Moat is $1.3 \mathrm{~m}$ a.s.l. Higher water levels will result in flooding of the city.

Depending on water levels in the Martwa Vistula caused by storm surges and the inflow to Motława Moat from the landward side, various situations are possible. One example is shown in Fig. 12. This figure shows the situation where the Motława River discharge is $12 \mathrm{~m}^{3} / \mathrm{s}$ and it coincides with a storm of probability $p=0.3 \%$. The gates close when the water level in the Martwa Vistula exceeds the water level in the Motława Moat and remains closed for about 30 hours while the Motława Moat fills with water to the level $0.85 \mathrm{~m}$, close to the permissible level. During this time the storm surge ends and the water level in the Motława Moat drops due to the decreased water level in the Martwa Vistula. Subsequently, the situation returns to normal.

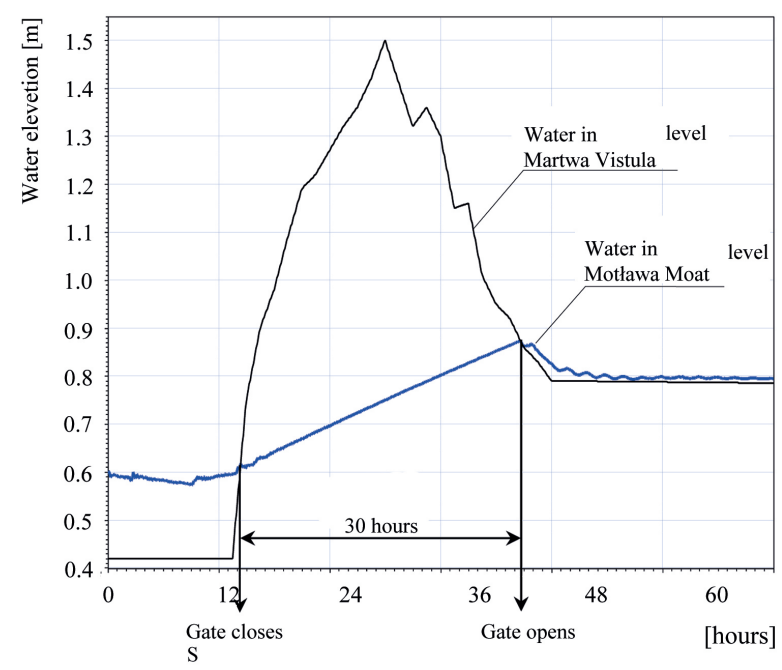

Fig. 12. Water levels in the Martwa Vistula and Motława Moat for discharge in the Motława River $12 \mathrm{~m}^{3} / \mathrm{s}$ and probability of water level in the Martwa Vistula $p=0.3 \%$ 


\section{Proposed engineering solutions}

The existing spatial situation of the city of Gdańsk indicates the difficulty in the carrying out of any general change in the network of channels in the Gdańsk area. The $\mathrm{RCh}$ is of great importance for possible floods caused by intensive precipitation in the city of Gdańsk. It was found that there is no possibility of significantly increasing the discharge capacity of the RCh. Moreover, the RCh is a technological monument and change of its construction or layout requires acceptance from the Gdańsk Architect's Office.

In order to decrease the inflow to the $\mathrm{RCh}$ in the case of intensive precipitation it was decided, on the basis of hydraulic calculations, that 18 small reservoirs on all streams discharging to the $\mathrm{RCh}$ should be constructed, and that 4 control outflows from the $\mathrm{RCh}$ to the Radunia and Motława Rivers should be installed. In addition, 2 flood polders were proposed in case of extreme situations. The proposed constructions are expensive and it will take several years to put them into operation (Fig. 11).

It was also proposed that automatic precipitation and water level gauges in the GWN should be installed to create, together with meteorological radar, a flood warning system.

\section{Conclusions}

The main reason for the flood was very intensive precipitation, which concentrated on the RCh catchment and resulted in high runoff to the channel. The channel could not transfer this high discharge, and as a consequence the right side embankment was breached in 5 places. This resulted in significant damage to city infrastructure.

The main destruction within the city concerned the area on the right side of the RCh. After the flood, the damaged right side embankment of the $\mathrm{RCh}$ and the main road were repaired. The railway station returned to service after one week.

Beyond this area, Kłodawa River embankment was breached and a large amount of agricultural land was flooded. The embankment was repaired and the flooded area drained. In another part of the city the dam of the reservoir on the Strzyża Stream was breached and an important road crossing was flooded. It took 2 days for the road crossing on the main road between Gdańsk and Gdynia to become operational. The total loss to city infrastructure was estimated at 40 million euros.

The special project was developed after the flood with the aim of proposing new hydraulic solutions to prevent flooding in cases of a similar rainfall. The project included the measurement of all rivers and channels of the GWN, hydrologic analysis of discharges in rivers of the GWN, and development of a 1D unsteady flow model. On the basis of previous hydraulic calculations, the Manning roughness coefficient was assumed as $n=0.030$.

Following on from the project, which has subsequently been completed, the following new engineering solutions were proposed:

- reconstruction of the whole length of the $\mathrm{RCh}$;

- construction of 18 new retention reservoirs on the streams of the RCh catchment in addition to the 4 existing reservoirs;

- construction of 4 new outlets from the RCh to Radunia and Motława Rivers of total discharge capacity $35 \mathrm{~m}^{3} / \mathrm{s}$;

- reconstruction of the outlets of streams to the $\mathrm{RCh}$ in order to change the direction of flow.

Construction of the reservoirs at the $\mathrm{RCh}$ catchment was necessary to increase the retention capacity and delay the runoff to the $\mathrm{RCh}$. Construction of new outlets from the RCh was necessary to remove water from the channel in a controlled way in cases of intensive runoff from the $\mathrm{RCh}$ catchment. The increase in discharge capacity of the $\mathrm{RCh}$ was not possible, because this would require substantial changes to the channel flow cross-section; this is not possible. Calculations of discharge and water levels with new hydraulic structures were carried out; they indicated that there is no flood hazard in the case of rainfall similar to that in 2001.

Hydraulic calculations of the operation of storm gates at the Motława Moat (1 and 2 shown in Fig. 1) in connection with the discharge into the Motława River were also carried out.

The proposed new hydraulic structures were gradually implemented. The reconstructed RCh is shown in Fig. 13,

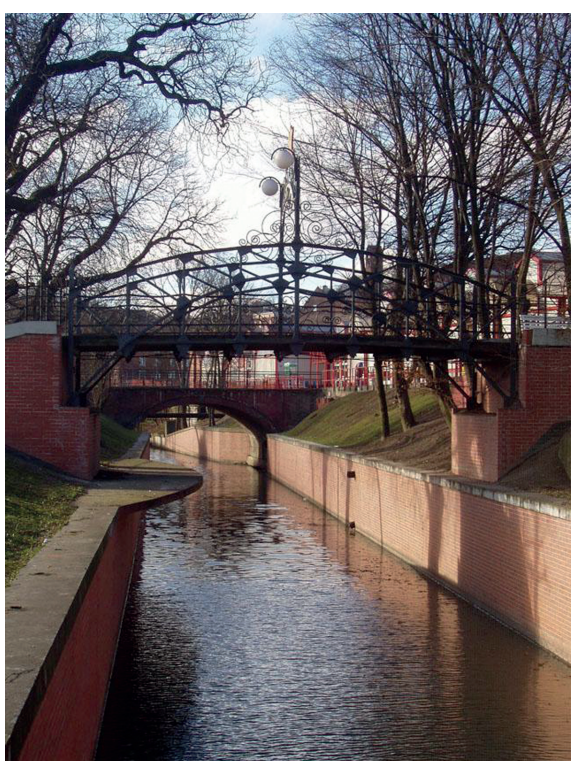

Fig. 13. RCh after reconstruction (Internet Gdańsk) 


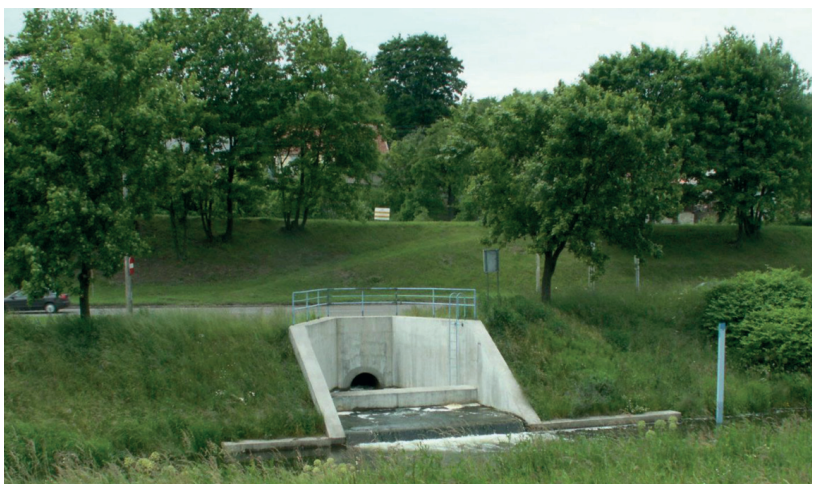

Fig. 14. New outlet from the RCh to Radunia River. In the background is the road to Gdańsk and the embankment of Radunia Channel. Maximum discharge through this outlet is $13.0 \mathrm{~m}^{3} / \mathrm{s}$ (Majewski 2010)

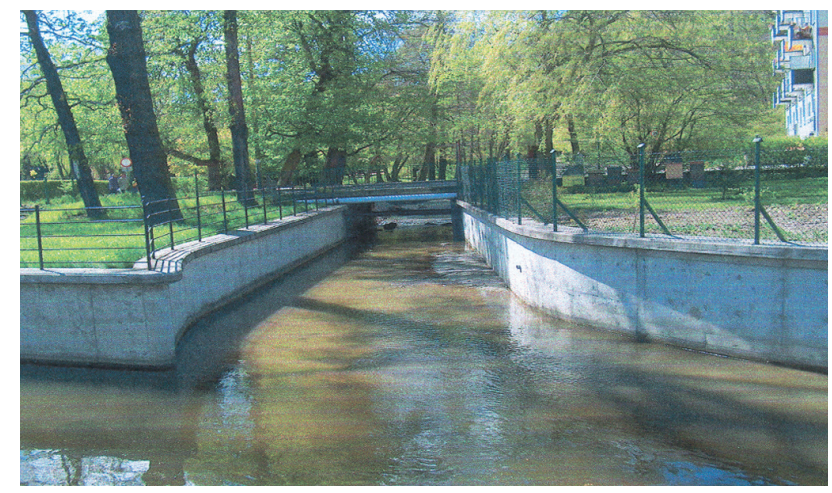

Fig. 16. New modified outlet of a stream to the RCh (Majewski 2010)

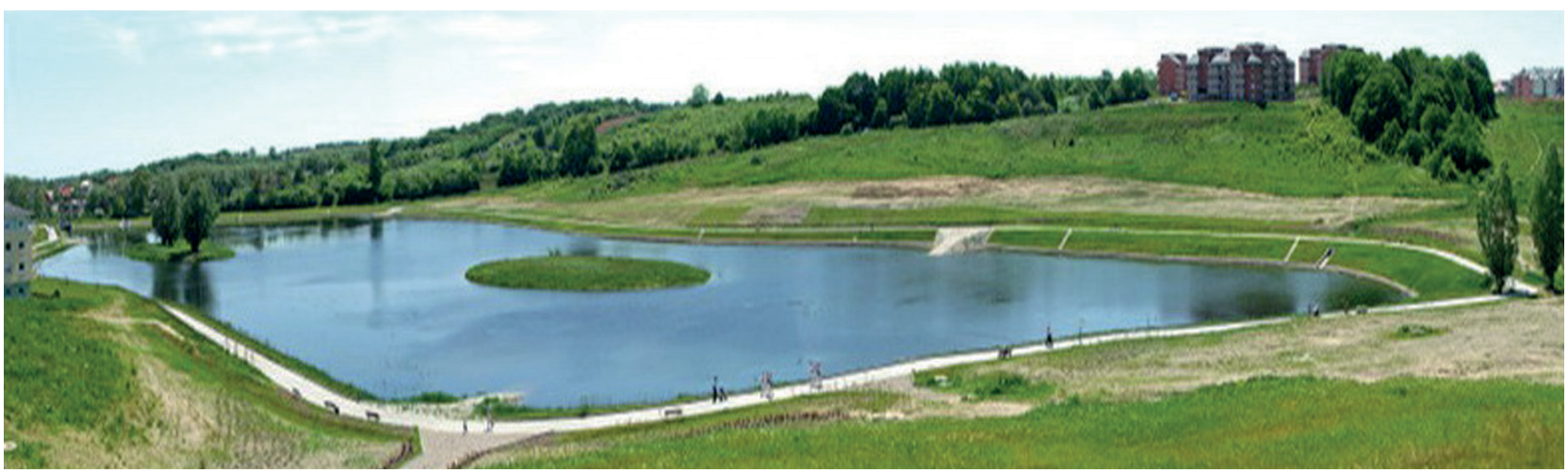

Fig. 15. New retention reservoir in the RCh catchment (Majewski 2010)

and a new outlet from the RCh to the Radunia River is presented in Fig. 14. One of the retention reservoirs is shown in Fig. 15, and a modified outlet of one of the streams into the RCh is shown in Fig. 16.

\section{Bibliography}

Jasińska E., 2002, Hydrology and hydrodynamics of the Martwa Vistula and Vistula Przekop, (in Polish), Wydawnictwo Instytutu Budownictwa Wodnego Polskiej Akademii Nauk, Gdańsk, 133 pp.

Jasińska E., Majewski W., 2004, Flood problems in the city of Gdańsk, [in:] Proceedings of the $37^{\text {th }}$ DEFRA Flood and Coastal Management Conference, London, 1-12

Majewski W., 2002, Flood in Gdańsk in July 2001, [in:] Proceedings of the Second Annual IIASA-DPRI Meeting "Integrated Disaster Risk Management: Megacity Vulnerability and Resilience”, 29-31 July, IIASA Laxenburg, Austria
Majewski W., 2003a, The Flood in Gdańsk in July 2001; proposals for future protection, (in Polish), Proceedings of the Conference Flood in Gdańsk 2001, Gdańskie Towarzystwo Naukowe, Gdańsk

Majewski W. (ed), 2003b, The model of water distribution in the Gdańsk Water Node for flood protection in the Martwa Vistula catchment, (unpublished internal report, in Polish), Instytut Budownictwa Wodnego Polskiej Akademii Nauk, Gdańsk

Majewski W. (ed.), 2004, The model of water distribution in the Gdańsk Water Node for flood protection in the Martwa Vistula catchment, (unpublished internal report, in Polish), Instytut Budownictwa Wodnego Polskiej Akademii Nauk, Gdańsk

Majewski W., 2010, Flood in Gdańsk in July 2001, (in Polish), IMGW-PIB, Warszawa, 110 pp.

Szermer B., 1971, Gdańsk - past and present, (in Polish), Interpress, Warszawa 